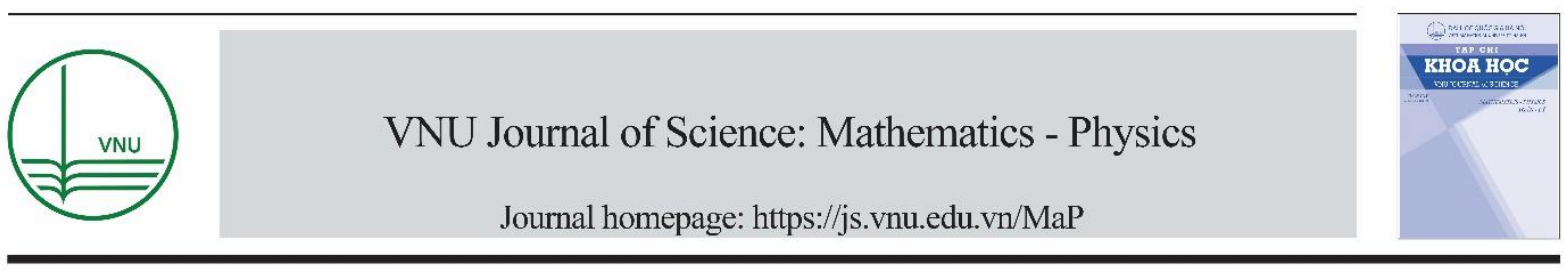

Original Article

\title{
Fabrication and Characterization of $\mathrm{CoFe}_{2} \mathrm{O}_{4} / \mathrm{CoFe}_{2} / \mathrm{SiO}_{2}$ Nanocomposite Particles
}

\author{
Tran Thi Viet Nga* \\ International Training Institute for Materials Science (ITIMS), \\ Hanoi University of Science and Technology, No. 1 Dai Co Viet, Hanoi, Vietnam \\ Received 06 March 2020 \\ Revised 21 April 2020; Accepted 17 August 2020
}

\begin{abstract}
The $\mathrm{CoFe}_{2} \mathrm{O}_{4} / \mathrm{CoFe}_{2} / \mathrm{SiO}_{2}$ nanocomposite particles were synthesized using a sol- gel method and calcination in hydrogen. The magnetic properties and structure of nanocomposite particles calcinated at $600{ }^{\circ} \mathrm{C}$ and $900{ }^{\circ} \mathrm{C}$ in range of calcination time from $1 \mathrm{~h}$ to $4 \mathrm{~h}$ were investigated. The phase composition, surface morphology and magnetic properties of the nanocomposites were investigated using X-ray powder diffraction, scanning electron microscopy and vibrating sample magnetometer. The XRD patterns indicate the existence of both $\mathrm{CoFe}_{2} \mathrm{O}_{4}$ and $\mathrm{CoFe}_{2}$ phases in the nanocomposite after reducing at $600{ }^{\circ} \mathrm{C}$ for $2 \mathrm{~h}$ and $3 \mathrm{~h}$. The single phase $\mathrm{CoFe}_{2}$ was obtained after reducing at $900{ }^{\circ} \mathrm{C}$. The average particles size was evenly distributed in the range of $20 \mathrm{~nm}$ to $120 \mathrm{~nm}$. The magnetization increases significantly with increasing of reduction temperature.
\end{abstract}

Keywords: Sol-gel synthesis, nanocomposite, core- shell, exchange coupled.

\section{Introduction}

Nanocomposite particles based on the exchange spring mechanism have become a hot research topic in recent time because of their superior performances [1-3]. According to Kneller and Hawig [4], the composite magnets consisting of a hard magnetic phase and a soft magnetic phase have an inter-phase exchange interaction. The combining of two phases brings about enhancement in the magnetic properties of a magnet. So, the composite magnet has the high magnetization from the soft phase and large coercivity from the hard phase, which makes them suitable for the applications of permanent magnets. For example, magnetic micro electromechanical systems (MEMS) including microactuators, sensors,

\footnotetext{
*Corresponding author.

Email address: vietnga@itims.edu.vn
}

https//doi.org/ 10.25073/2588-1124/vnumap.4481 
recording heads and micro-motors, spins of electron devices apply in spin- valve read heads [5-7]. Nowadays, nanocomposite particles and core/shell structured nanoparticles having been paid much attention to research. Some kinds of nanocomposite particles have been synthesized, such as $\mathrm{CoFe}_{2} \mathrm{O}_{4} /$ $\mathrm{Fe}_{3} \mathrm{O}_{4}$ [8], $\mathrm{SrFe}_{12} \mathrm{O}_{19^{-}} \mathrm{CoFe}_{2} \mathrm{O}_{4}$ [9, 3], $\mathrm{BaFe}_{12} \mathrm{O}_{19} / \mathrm{Fe}_{3} \mathrm{O}_{4}$ [10], $\mathrm{CoFe}_{2} \mathrm{O}_{4^{-}} \mathrm{CoFe}_{2}$ [11]. The saturation magnetization is enhanced markedly with the increase of magnetically soft phase content. For example, in the $\mathrm{BaFe}_{12} \mathrm{O}_{19} / \mathrm{Fe}_{3} \mathrm{O}_{4}$ nanocomposite particles, the saturation magnetization increases $22.9 \%$ when the ratio $\mathrm{BaFe}_{12} \mathrm{O}_{19} / \mathrm{Fe}_{3} \mathrm{O}_{4}=3 / 1$. A maximum energy product $(\mathrm{BH})_{\max }$ of $1.22 \mathrm{MGOe}$ was achieved at room temperature for $\mathrm{CoFe}_{2} \mathrm{O}_{4} / \mathrm{CoFe}_{2}$ nanocomposites, which is about $115 \%$ higher than the value obtained for $\mathrm{CoFe}_{2} \mathrm{O}_{4}$ precursor [11]. For the nanocomposite particles, contact area between the aggregated particles is limited so that they could not be sufficiently exchange coupled. In order to make the two phases contacted sufficiently, attempts have been done to synthesize nanocomposite particles with core- shell structure. Although the core/shell structured nanoparticles are less studied, their potential in electromagnetic and magnetic applications is large. In such a system, the intimate contact between, the core and shell leads to effective exchange coupling and therefore cooperative magnetic switching, facilitating the fabrication of nanostructured magnetic materials with tunable properties. In 2004, Hao Zeng et al. researched $\mathrm{FePt} / \mathrm{MFe}_{2} \mathrm{O}_{4}(\mathrm{M}=\mathrm{Fe}$ and $\mathrm{Co})$ core/shell nanoparticles synthesized by hydrothermal method [12], the exchange coupling between particles were observed in all of samples. The coercivity of $\mathrm{FePt} / \mathrm{Fe}_{3} \mathrm{O}_{4}$ nanoparticle is $2.3 \mathrm{kOe}$, which is smaller than that of $\mathrm{FePt}$ nanoparticles (5.5 kOe), while that of $\mathrm{FePt} / \mathrm{CoFe}_{2} \mathrm{O}_{4}$ reached $8 \mathrm{kOe}$. In 2015, Juan et al. have been studied hard/soft $\mathrm{SrFe}_{12} \mathrm{O}_{19} / \mathrm{Fe}$-Co composite nanofibers with core- shell structure are synthesized by reduction process in a hydrogen atmosphere [2]. The core- shell nanofibers show an enhanced saturation magnetization $\left(M_{\mathrm{s}}\right)$ of $60.9 \mathrm{emu} / \mathrm{g}$ for $\mathrm{SrFe}_{12} \mathrm{O}_{19} / \mathrm{CoFe}_{2} \mathrm{O}_{4}$ and $68.8 \mathrm{emu} / \mathrm{g}$ for $\mathrm{SrFe}_{12} \mathrm{O}_{19} / \mathrm{FeCo}$ comparing with $\mathrm{SrFe}_{12} \mathrm{O}_{19}$ nanofibers $(53.4 \mathrm{emu} / \mathrm{g})$. The coercivities $\left(H_{\mathrm{C}}\right)$ for $\mathrm{SrFe}_{12} \mathrm{O}_{19} / \mathrm{CoFe}_{2} \mathrm{O}_{4}$ and $\mathrm{SrFe}_{12} \mathrm{O}_{19} / \mathrm{FeCo}$ core- shell nanofibers decrease to 3190 Oe and 1249 Oe, respectively. The hysteresis loop of the coreshell nano fibers shows a single-phase magnetization behavior, implying that the magnetic hard $\left(\mathrm{SrFe}_{12} \mathrm{O}_{19}\right)$ phase and soft (FeCo alloy) phase are well exchange- coupled.

It is well known that Cobalt ferrite $\mathrm{CoFe}_{2} \mathrm{O}_{4}$ is a popular hard magnetic because of high magnetocrystalline anisotropy, low cost and high chemical stability. Therefore it is a candidate of the hard magnetic for researching the exchange coupling behavior in the nanocomposites. The recent researchs show that the $\mathrm{CoFe}_{2} \mathrm{O}_{4} / \mathrm{CoFe}_{2}$ with core- shell structure can be easily prepared by reducing $\mathrm{CoFe}_{2} \mathrm{O}_{4}[11,13]$. Otherwise, magnetic particles tend to agglomerate. So, in this paper, we chose nonmagnetic $\mathrm{SiO}_{2}$ to coat on $\mathrm{CoFe}_{2} \mathrm{O}_{4} / \mathrm{CoFe}_{2}$ nanoparticles by reducing $\mathrm{CoFe}_{2} \mathrm{O}_{4} / \mathrm{SiO}_{2}$ nanoparticles in hydrogen at different temperatures. The effects of the reduction time $\left(t_{\mathrm{r}}\right)$ and calcination temperature $\left(T_{\mathrm{c}}\right)$ on structural and magnetic properties of samples are investigated.

\section{Experiment}

$\mathrm{CoFe}_{2} \mathrm{O}_{4} / \mathrm{SiO}_{2}$ powders with the mass ratio of $\left(\mathrm{Co}^{2+}+\mathrm{Fe}^{3+}\right)$ and $\mathrm{SiO}_{2}$ of $3: 1$ were synthesized by a sol- gel method. $\mathrm{Fe}\left(\mathrm{NO}_{3}\right)_{3} .9 \mathrm{H}_{2} \mathrm{O}$ and $\mathrm{Co}\left(\mathrm{NO}_{3}\right)_{2}$ were dissolved in deionized water to form aqueous $1 \mathrm{M}$ solution and then citric acid was added. The molar ratio of solutes in the solution was $\mathrm{Co}^{2+}: \mathrm{Fe}^{3+}$ : $\mathrm{C}_{3} \mathrm{H}_{4}(\mathrm{OH})(\mathrm{COOH})_{3}=1: 2: 3$. We use $\mathrm{NH}_{4} \mathrm{OH}$ to adjust the $\mathrm{pH}$ of the solution 1 . After the $\mathrm{pH}$ had stabilized, tetraethyl orthosilicate $\mathrm{SiO}_{2}$ (TEOS) was added into the solution with the ratio of $\left[\mathrm{Co}^{2+}+\mathrm{Fe}^{3+}\right.$ $\left.+\mathrm{C}_{3} \mathrm{H}_{4}(\mathrm{OH})(\mathrm{COOH})_{3}\right]: \mathrm{SiO}_{2}=3: 1$. The solution was stirred at $1000 \mathrm{rpm}$ and gradually evaporated at $70{ }^{\circ} \mathrm{C}$. After the water evaporated, the remainder became highly viscous gel with red- brown color as a result of the chelation process. The gel was dried at $80^{\circ} \mathrm{C}$ for $24 \mathrm{~h}$ and then heated at $300{ }^{\circ} \mathrm{C}$ for $2 \mathrm{~h}$ to eliminate the remaining residual water and other organic impurities (aerogel was formed). To form the 
$\mathrm{CoFe}_{2} \mathrm{O}_{4} / \mathrm{CoFe}_{2} / \mathrm{SiO}_{2}$ nanocomposite particles, the gels were reduced in hydrogen at $600{ }^{\circ} \mathrm{C}$ and $900{ }^{\circ} \mathrm{C}$ temperatures for different times, promoting the following chemical reduction:

$$
\mathrm{CoFe}_{2} \mathrm{O}_{4}+\mathrm{H}_{2} \rightarrow \mathrm{CoFe}_{2}+\mathrm{H}_{2} \mathrm{O}
$$

The crystal structure and phases of the obtained samples were identified via $\mathrm{X}$ - ray powder diffraction (XRD) using a Siemens D5000 diffractometer (CuKa radiation, $\lambda=1.54056 \AA$ ). Morphological features and particle size were observed by Transmission Electron Microscopy (TEM) and Scanning Electron Microscopy (SEM). The magnetic properties were measured using a vibrating sample magnetometer (VSM, Lakeshore 7410) with applied magnetic fields up to $10 \mathrm{kOe}$. Thermogravimetric analyses (TGA) were employed to study thermal behavior using a Universal V2960T with a heating rate of $10{ }^{\circ} \mathrm{C} / \mathrm{min}$ in air, whereas pure alumina powder was used as the reference specimen. The synthesis and characterization of the samples are shown in Figure 1.

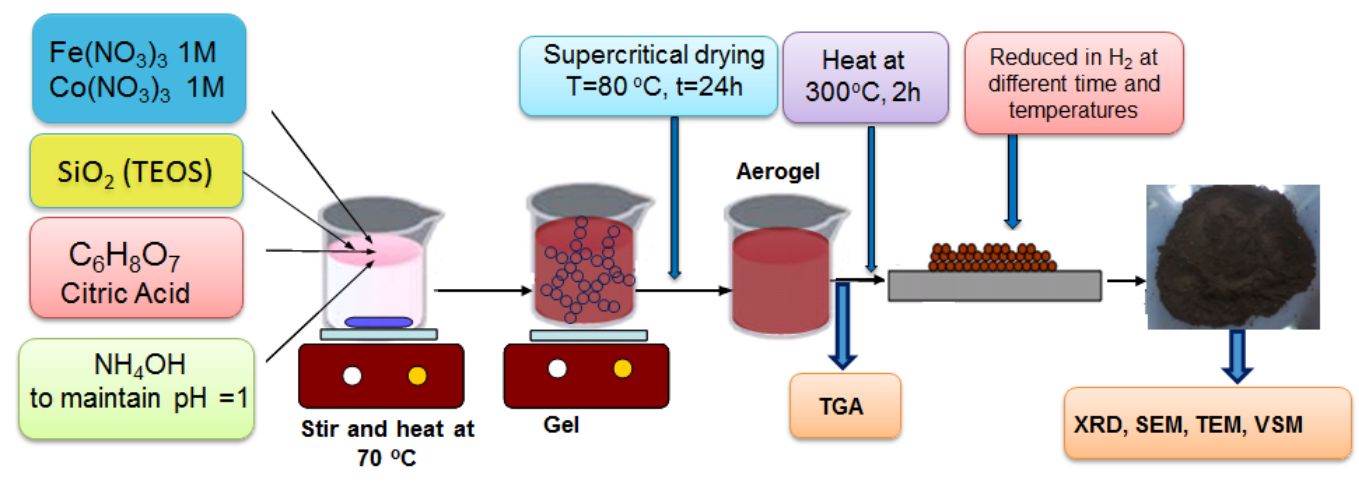

Figure 1. Flowchart for preparation of $\mathrm{CoFe}_{2} \mathrm{O}_{4} / \mathrm{CoFe}_{2} / \mathrm{SiO}_{2}$ nanocomposite particles.

\section{Results and Discussion}

The TGA of gel precursor $\mathrm{CoFe}_{2} \mathrm{O}_{4} / \mathrm{SiO}_{2}$ is shown in figure 2. The experiment was performed using $36.746 \mathrm{mg}$ of gel precursor and a heating of $10{ }^{\circ} \mathrm{C} / \mathrm{min}$ in static air. At approximately $136{ }^{\circ} \mathrm{C}$ of temperature, the weight loss of $20 \%$. It was attributed to the decomposition of $\mathrm{NH}_{4} \mathrm{NO}_{3}$ to liberate $\mathrm{NO}$, $\mathrm{O}_{2}$, and $\mathrm{H}_{2} \mathrm{O}$. The exothermic peak at approximately $225{ }^{\circ} \mathrm{C}$ showed the decomposition of the remaining unreactive organic material induced by excess citric and weight loss of $85.05 \%$. At the approximately $306{ }^{\circ} \mathrm{C}$, the weight loss about $86.47 \%$ and the crystallization process of the main phase may be obtained at higher temperature $\left(306{ }^{\circ} \mathrm{C}\right)$ following equation 1 . Based on the results obtained from the thermal analysis of the precursor (figure 2), we choose $300{ }^{\circ} \mathrm{C}$ of temperature for heating gels and eliminating the remaining residual water and other organic impurities.

To investigate the monitor phase development with reducing time $\left(t_{\mathrm{r}}\right)$, the obtained xerogel was reduced in hydrogen at $600{ }^{\circ} \mathrm{C}$ and $900{ }^{\circ} \mathrm{C}$. Figure. 3 shows the XRD patterns of the samples reduced at $600{ }^{\circ} \mathrm{C}$ and $900{ }^{\circ} \mathrm{C}$ with different time $t_{\mathrm{r}}(1$ hour, 2 hours, 3 hours and 4 hours). The XRD results indicate that the samples which reduced at $600{ }^{\circ} \mathrm{C}$ for $1 \mathrm{~h} \mathrm{CoFe}{ }_{2} \mathrm{O}_{4}$ phase is formed. The samples reduced at $600{ }^{\circ} \mathrm{C}$ in $2 \mathrm{~h}$ and $3 \mathrm{~h}$ compose two phases: main phase $\mathrm{CoFe}_{2}$ and a little of $\mathrm{CoFe}_{2} \mathrm{O}_{4}$ phase which appear at about $35.4^{\circ}$ and $62.5^{\circ}$. When increasing reduction temperature and time, all the samples only compose $\mathrm{CoFe}_{2}$ phase. The peaks of $\mathrm{CoFe}_{2}$ phase appear at about $45^{\circ}$ and $65^{\circ}$. The strength of the peaks 
of $\mathrm{CoFe}_{2}$ phase increases obviously with increasing reduction temperature and time. There is not a characteristic of amorphous $\mathrm{SiO}_{2}$ for all the sample. The average crystallite size is calculated using Debays' Scherrer equation. The lattice constant $(a)$, volume of the unit cell $(V)$ are calculated from the expression $a=d \sqrt{h^{2}+l^{2}+k^{2}}$. The lattice constant $a$, average crystallite size $D$ and volume of the unit cell $V\left(a^{3}\right)$ of $\mathrm{CoFe}_{2} \mathrm{O}_{4}$ and $\mathrm{CoFe}_{2}$ nanoparticles in the nanoparticles are listed in table 1 . The average crystallite size $\mathrm{D}$ increase with increasing of reduction temperature and time.

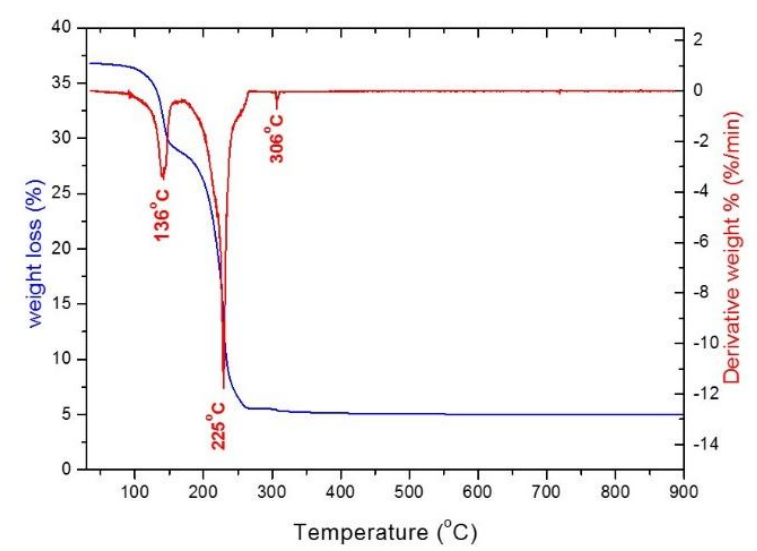

Figure 2. Thermogravimetric (TGA) curve of the gel precursor $\mathrm{CoFe}_{2} \mathrm{O}_{4} / \mathrm{SiO}_{2}$.

Table 1. XRD refinement results: lattice parameters $(a)$, average size of coherent scattering region $(D)$ and volume unit $(V)$ in the samples.

\begin{tabular}{|c|c|c|c|}
\hline $\begin{array}{c}\text { Characteristic parameter/ } \\
\text { reduction temperature }\end{array}$ & $a(\AA)$ & $D(n m)$ & $V(\AA)^{3}$ \\
\hline $600^{\circ} \mathrm{C} 1 \mathrm{~h}$ & 8.345 & 10.0 & 581.14 \\
\hline $600^{\circ} \mathrm{C} 2 \mathrm{~h}$ & 2.862 & 20.12 & 23.44 \\
\hline $600^{\circ} \mathrm{C} 3 \mathrm{~h}$ & 2.871 & 21.34 & 23.66 \\
\hline $600^{\circ} \mathrm{C} 4 \mathrm{~h}$ & 2.869 & 20.31 & 23.62 \\
\hline $900^{\circ} \mathrm{C} 1 \mathrm{~h}$ & 2.875 & 30.02 & 23.76 \\
\hline $900^{\circ} \mathrm{C} 2 \mathrm{~h}$ & 2.867 & 31.24 & 23.59 \\
\hline $900^{\circ} \mathrm{C} 3 \mathrm{~h}$ & 2.870 & 30.94 & 23.64 \\
\hline $900^{\circ} \mathrm{C} 3 \mathrm{~h}$ & 2.873 & 31.32 & 23.71 \\
\hline
\end{tabular}

Scanning electron micrographs of samples are shown in figure 4 . We can see clearly from the micrographs that samples reduced at $600{ }^{\circ} \mathrm{C}$ show agglomeration to certain amount. The particles size distribute from $10 \mathrm{~nm}$ to $20 \mathrm{~nm}$ and the samples exhibits nearly spherical morphology. For samples reduced at $900{ }^{\circ} \mathrm{C}$, the particles size is lager and distribute from $80 \mathrm{~nm}$ to $120 \mathrm{~nm}$. The particles exhibit cubic morphology for the sample reduced in $1 \mathrm{~h}$. When increase the reduction time $(3 \mathrm{~h})$, sample consisted of triangle morphology particles. This phenomenon can be understood via the development of grain size and breaking of grains with increase in the reduction time. Figure 5 shows the transmission electron micrographs of the samples reduced at $600^{\circ} \mathrm{C}$ for $1 \mathrm{~h}$ and $900^{\circ} \mathrm{C}$ for $1 \mathrm{~h}$. The samples show non uniform morphology and the particles are virtually spherical morphology. The micrographs have the formation of large agglomerates of nanoscale particles. 



Figure 3. XRD patterns of $\mathrm{CoFe}_{2} \mathrm{O}_{4} / \mathrm{CoFe}_{2} / \mathrm{SiO}_{2}$ nanocomposite samples:

(a) reduced at $600{ }^{\circ} \mathrm{C}$ for different times; (b) reduced at $900{ }^{\circ} \mathrm{C}$ for different times
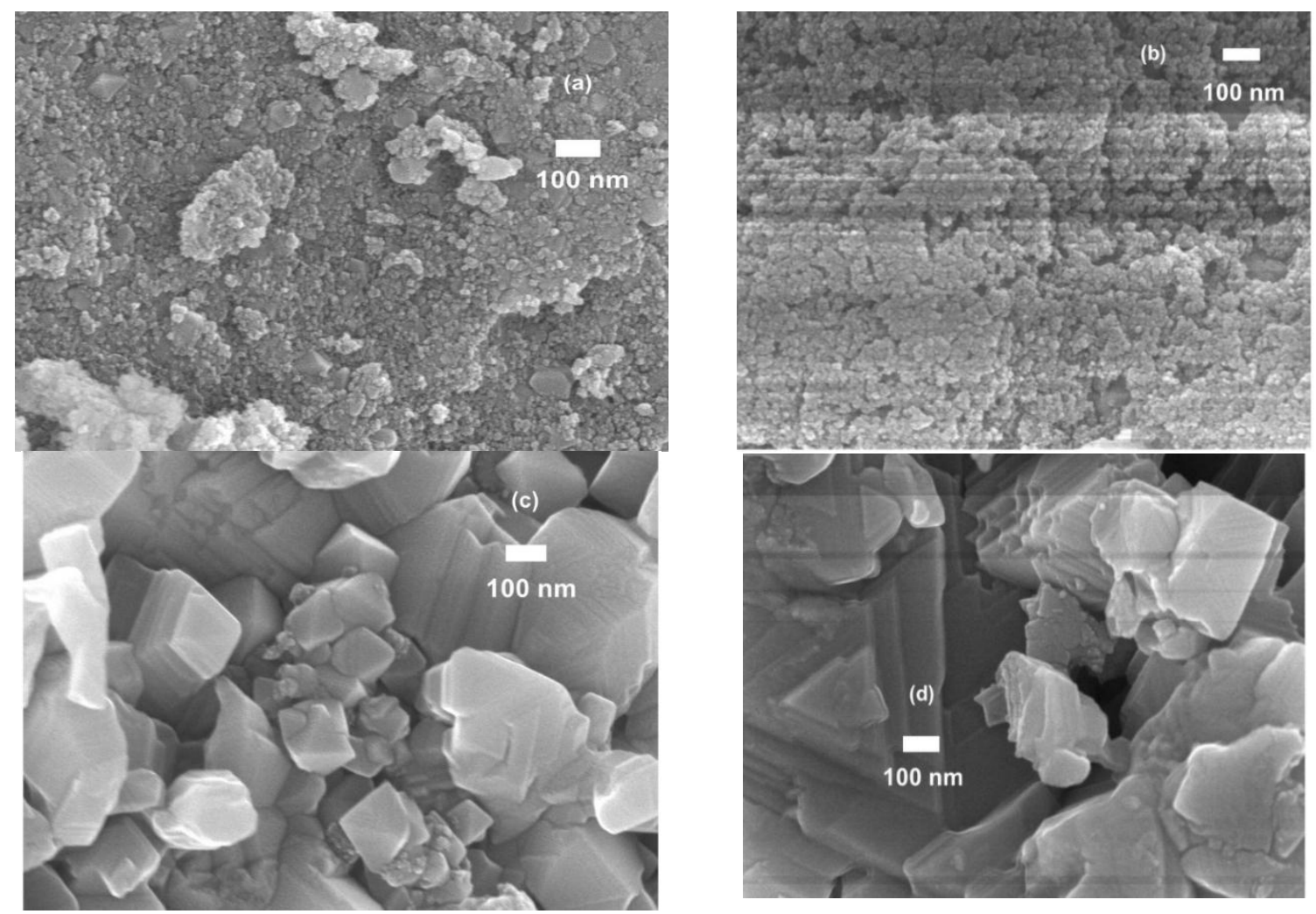

Figure 4. SEM micrographs of samples reduced at: a) $600{ }^{\circ} \mathrm{C}$ for $1 \mathrm{~h}$; b) $600{ }^{\circ} \mathrm{C}$ for $3 \mathrm{~h}$; c) $900{ }^{\circ} \mathrm{C}$ for $1 \mathrm{~h}$ and d) $900{ }^{\circ} \mathrm{C}$ for $3 \mathrm{~h}$. 




(a)

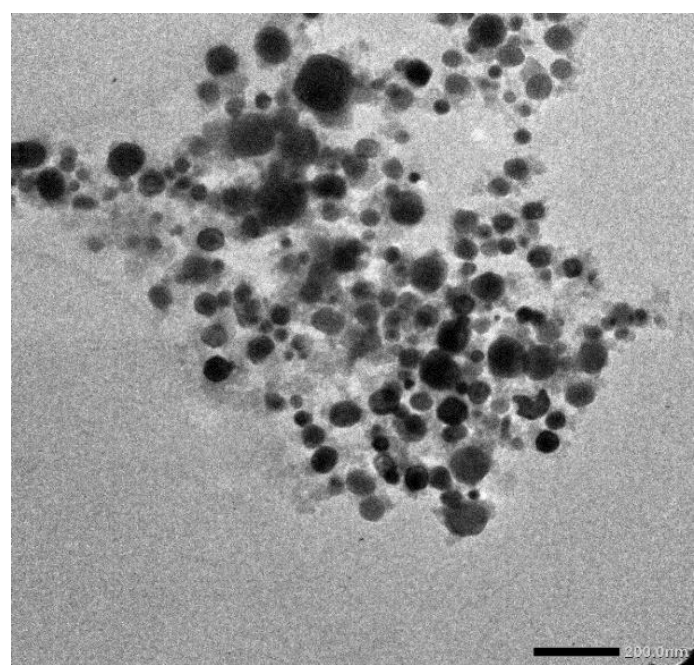

(b)

Figure 5. TEM of the samples reduced at (a) $600{ }^{\circ} \mathrm{C}$ for $1 \mathrm{~h}$ and (b) $900{ }^{\circ} \mathrm{C}$ for $1 \mathrm{~h}$
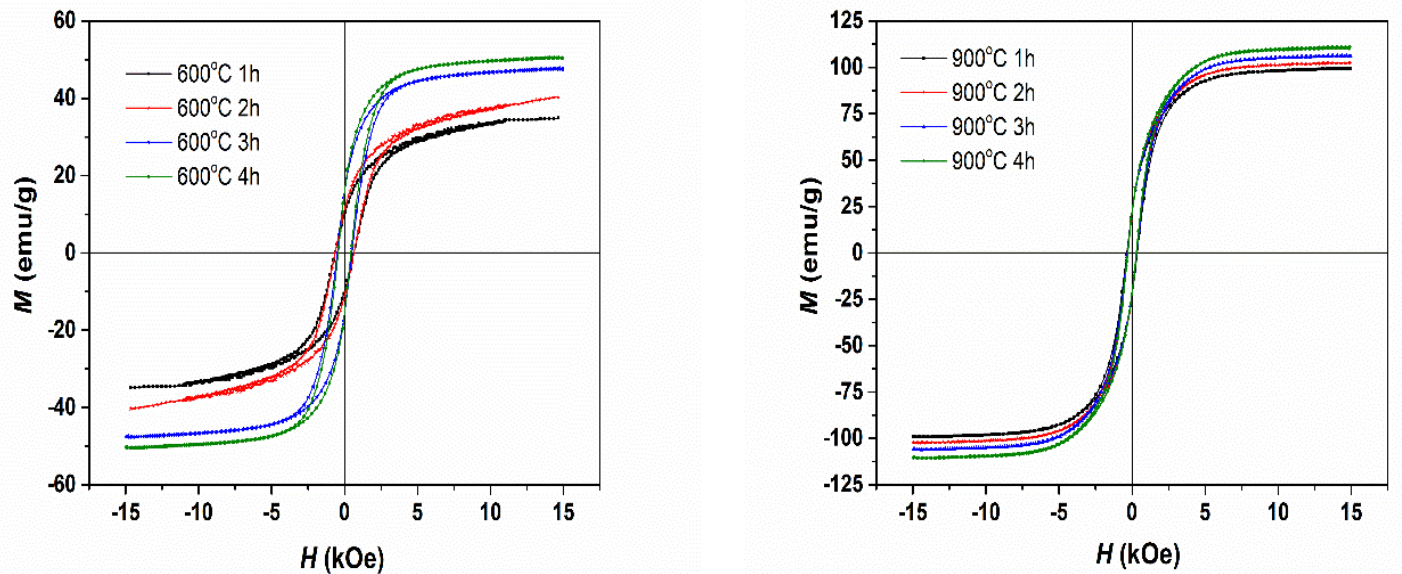

Figure 6. Hysteresis loops of $\mathrm{CoFe}_{2} \mathrm{O}_{4} / \mathrm{CoFe}_{2} / \mathrm{SiO}_{2}$ nanocomposite samples.

The magnetic properties of the samples were measured at room temperature via VSM. The hysteresis loops are illustrated in figure 6. The samples exhibited a magnetically soft behavior. As seen in the figure 6, all samples exhibit a smooth hysteresis loop and show a single-phase magnetization behavior. The magnetization at $15 \mathrm{kOe}$ increased from $34.6 \mathrm{emu} / \mathrm{g}$ to $50.51 \mathrm{emu} / \mathrm{g}$ and from $99.39 \mathrm{emu} / \mathrm{g}$ to 140.37 emu/g when the reduction time increased from $1 \mathrm{~h}$ to $4 \mathrm{~h}$ at $600{ }^{\circ} \mathrm{C}$ and $900{ }^{\circ} \mathrm{C}$, respectively. As expected, the magnetic properties of nanocomposite particles can be enhanced with a strong exchange coupling. For the samples reduced at $600{ }^{\circ} \mathrm{C}$ for $2 \mathrm{~h}$ and $3 \mathrm{~h}$, although their crystallo- graphically compose of two phases, the hysteresis loop exhibits a single- phase magnetization behavior. It indicates two magnetic phases are switching individually due to the incomplete exchange- coupling $[3,11,14]$. The dependence of magnetization $M$ (at $15 \mathrm{kOe}$ ) and coercivity $H_{\mathrm{C}}$ on reduction time is shown in figure. 7 . The reducing $H_{\mathrm{C}}$ of these samples with increasing reduction time may be due to the growth of particles size and the 
dense presence of $\mathrm{CoFe}_{2}$ phase. Otherwise, as concentration of the soft phase increases, the role of dipolar interactions among the soft grains becomes more important [3] and the reverse domains in soft phase with low nucleation field nucleate readily. Thus, the value of $H_{\mathrm{C}}$ decreases. When increasing the reduction time, the $H_{\mathrm{C}}$ of samples reduced at $900{ }^{\circ} \mathrm{C}$ are almost unchanged. It is due to the competition between the growth particle size and a strong exchange coupling spring in these samples.
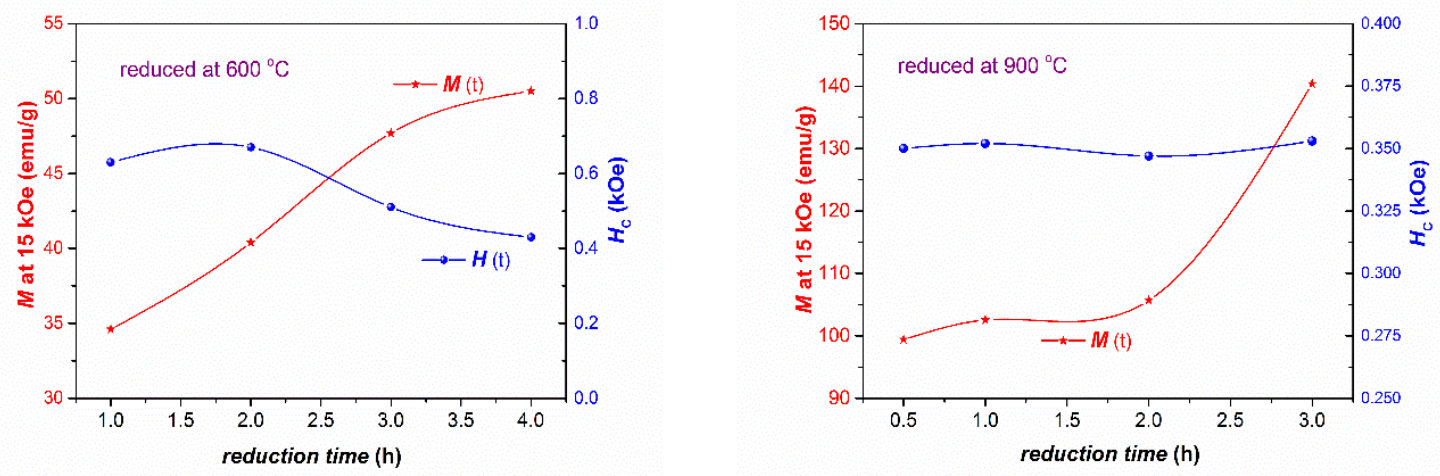

Figure 7. The variation in magnetization $M$ (at $15 \mathrm{kOe}$ ) and coercive force $\left(H_{\mathrm{C}}\right)$ with increasing of reduction time.

\section{Conclusion}

The $\mathrm{CoFe}_{2} \mathrm{O}_{4} / \mathrm{CoFe}_{2} / \mathrm{SiO}_{2}$ nanocomposites particles are prepared by sol-gel method. The particles displayed a spherical shape with particle size distribute from $10 \mathrm{~nm}$ to $20 \mathrm{~nm}$ and from $80 \mathrm{~nm}$ to 120 $\mathrm{nm}$ after reducing at $600{ }^{\circ} \mathrm{C}$ and $900{ }^{\circ} \mathrm{C}$, respectively. The XRD patterns confirmed the coexistence of $\mathrm{CoFe}_{2} \mathrm{O}_{4}$ and $\mathrm{CoFe}_{2}$ phases after reducing at $600{ }^{\circ} \mathrm{C}$ in $2 \mathrm{~h}$ and $3 \mathrm{~h}$. When increasing reduction temperature and time, samples only compose $\mathrm{CoFe}_{2}$ phase. The magnetizations at $15 \mathrm{kOe}$ increase from $34.6 \mathrm{emu} / \mathrm{g}$ to $50.51 \mathrm{emu} / \mathrm{g}$ and from $99.39 \mathrm{emu} / \mathrm{g}$ to $140.37 \mathrm{emu} / \mathrm{g}$ when the reduction time increased from $1 \mathrm{~h}$ to $4 \mathrm{~h}$ at $600{ }^{\circ} \mathrm{C}$ and $900{ }^{\circ} \mathrm{C}$, respectively. The homogeneity of phases, grain size, and exchange coupling between the two phases among others may result in variations in coercivity and saturation magnetization of the nanocomposite samples.

\section{Acknowledgments}

This research was funded by the Vietnam National Foundation for Science and Technology Development under grant number 103.02-2017.16

\section{References}

[1] F. Song, X. Shen, M. Liu, and J. Xiang, Magnetic hard/soft nanocomposite ferrite aligned hollow microfibers and remanence enhancement, J. Colloid Interface Sci. 354 (1) (2011) 413-416.

[2] J. Dong, Y. Zhang, X. Zhang, Q. Liu, and J. Wang, Improved magnetic properties of $\mathrm{SrFe}_{12} \mathrm{O}_{19} / \mathrm{FeCo}$ core-shell nanofibers by hard/soft magnetic exchange-coupling effect, Mater. Lett., 120 (2014) 9-12.

[3] A. Xia, Suzhen Ren, Junshu Lin, Yue Ma, Chen Xu, Jinlin Li, Chuangui Jin, Xianguo, Magnetic properties of sintered $\mathrm{SrFe}_{12} \mathrm{O}_{19}-\mathrm{CoFe}_{2} \mathrm{O}_{4}$ nanocomposites with exchange coupling, J. Alloys Compd. 653 (2015) 108-116. 
[4] E.F. Kneller and R. Hawig, The exchange-spring magnet: A new material principle for permanent magnets, IEEE Trans. Magn. 274 (1991) 3588-3600.

[5] D.A. Allwood, G. Xiong, M.D. Cooke, C.C. Faulkner, D. Atkinson, R.P. Cowburn, Characterization of submicrometer ferromagnetic NOT gates, J. Appl. Phys. 95 (12) (2004) 8264-8270,

[6] Z. Wang, Xiaojuan Liu, Minfeng Lv, Ping Chai, Yao Liu, Xianfeng Zhou and Jian Meng, Preparation of onedimensional $\mathrm{CoFe} 2 \mathrm{O} 4$ nanostructures and their magnetic properties, J. Phys. Chem. C 112 (39) (2008) 1517115175.

[7] S.O. Hwang, C.H. Kim, Y. Myung, S.H. Park, J. Kim, C.S. Han, J.Y. Kim, Synthesis of vertically aligned manganese-doped $\mathrm{Fe}_{3} \mathrm{O}_{4}$ nanowire arrays and their excellent room-temperature gas sensing ability, J. Phys. Chem. C 112 (36) (2008) 13911-13916.

[8] F. Yi, Magnetic properties of hard $\left(\mathrm{CoFe}_{2} \mathrm{O}_{4}\right)$-soft $\left(\mathrm{Fe}_{3} \mathrm{O}_{4}\right)$ composite ceramics, Ceram. Int., 40 (6) (2014) $7837-$ 7840.

[9] D. Roy, P.S. Anil Kumar, Exchange spring behaviour in $\mathrm{SrFe}_{12} \mathrm{O}_{19}-\mathrm{CoFe}_{2} \mathrm{O}_{4}$ nanocomposites, AIP Adv. 5 (7) (2015) 0-11.

[10] K.P. Remya, D. Prabhu, S. Amirthapandian, C. Viswanathan, N. Ponpandian, Exchange spring magnetic behavior in $\mathrm{BaFe}_{12} \mathrm{O}_{19} / \mathrm{Fe}_{3} \mathrm{O}_{4}$ nanocomposites, J. Magn. Magn. Mater. 406 (2016) 233-238.

[11] G.C.P. Leite, E.F. Chagas, R. Pereira, R.J. Prado, A.J. Terezo, M. Alzamora, E. Baggio Saitovitch, Exchange coupling behavior in bimagnetic $\mathrm{CoFe}_{2} \mathrm{O}_{4} / \mathrm{CoFe}_{2}$ nanocomposite, J. Magn. Magn. Mater., 324 (18) (2012) 27112716.

[12] H. Zeng, S. Sun, J. Li, Z. L. Wang, and J. P. Liu, Tailoring magnetic properties of core/shell nanoparticles, Appl. Phys. Lett. 85 (5) (2004) 792-794.

[13] I.P. Ezekiel, T. Moyo, H.M.I. Abdallah, Magnetic properties of $\mathrm{CoFe}_{2} \mathrm{O}_{4} / \mathrm{CoFe}_{2}$ bi-magnetic nanocomposites synthesized by reduction process using activated charcoal in argon atmosphere, pp. 2-7.

[14] H. Yang, Miao Liu, Ying Lin, Guagiang Dong, Lingyan Hu, Ying Zhang and Jingyi Tan, Enhanced remanence and $(\mathrm{BH})_{\max }$ of $\mathrm{BaFe}_{12} \mathrm{O}_{19} / \mathrm{CoFe}_{2} \mathrm{O}_{4}$ composite ceramics prepared by the microwave sintering method, Mater. Chem. Phys. 160 (2015) 5-11. 